\title{
A Review on Effect of Covid-19 on Indian Sericulture Sector
}

\section{Priyanka Chamuah ${ }^{1 *}$, Debajit Borah ${ }^{2}$ and Shrishail Donaj ${ }^{3}$}

${ }^{1}$ PG Student, Department of Sericulture, FA, Assam Agricultural University, Jorhat, Assam, India

${ }^{2}$ Assistant Professor, Department of Extension Education, CS, Assam Agricultural University, Jorhat, Assam, India

${ }^{3}$ PG Student, Department of Extension Education, FA, Assam Agricultural University, Jorhat, Assam, India

* Corresponding author: priyanka.agri@rediffmail.com (ORCID ID: 0000-0003-0147-8180)

\begin{abstract}
Sericulture is an important agro-based industry that involves the production of silk by rearing silkworm. India is blessed with mulberry and vanya silk production due to its favourable climatic and topographic conditions. The ongoing covid-19 crisis has caused a drastic impact in the whole world. This has affected all walks of life, resulted in severe disruptions in all the world's economic activities, and the Indian economy is not an exception. The nationwide lockdown declared by the Indian Government has brutal consequences in every country's sectors from the economic growth and development point of view. Like other sectors in India, the sericulture sector has also witnessed the impact of the global pandemic. Due to the disturbance in the demand-supply chain, all the activities involved in the silk value chain have been hard hit by the covid-19 pandemic. Severe disruptions had happened in the availability of the inputs, cocoon and silk prices, raw silk production and marketing of the silk goods.
\end{abstract}

\section{HIGHLIGHTS}

(- Various activities involved in the sericulture sector were affected by the covid-19 pandemic.

(0 Difficulties in marketing of cocoons, silk and silk products.

( S Silk face mask became a boon to the industry.

( Initiatives of Government and Central Silk Board to become self-reliant in silk sector.

Keywords: Covid-19 pandemic, lockdown, sericulture sector, India, silk value chain, mulberry, vanya silk

Sericulture involves the production of raw silk by rearing silkworms. It is an agro-based industry that requires low capital investment and generates high income, capable of employing the people around the year. It is the only cash crop in the agricultural sector that gives output within 30 days (Das and Bhagabaty, 2018).

In India, silk is an indivisible part of its culture and traditions, and without silk, these rituals are incomplete. India is blessed with all the four commercial varieties of silk, namely, mulberry, eri, muga and tasar, due to its favorable climatic and topographic conditions. Silk production is considered an essential tool for the economic development of a country like India. The very nature of this industry with its rural-based onfarm and off-farm activities and enormous employment generation potential has attracted the attention of the

How to cite this article: Chamuah, P., Borah, D. and Donaj, S. (2021). A Review on Effect of Covid-19 on Indian Sericulture Sector. Int. J. Soc. Sci., 10(02): 173-179.

Source of Support: None; Conflict of Interest: None (क) 
planners and policymakers to recognize the industry among one of the most appropriate avenues for socioeconomic development of a largely agrarian economy like India (Bukhari and Kaur, 2019). Thus, sericulture is regarded as one of the essential sectors of India, which holds a particular position to solve the socio-economic problems and create regular employment in society.

The Sericulture industry has a long silk value chain that involves seed production, cocoon production, reeling, twisting, processing, weaving, finished goods making, and trading. These activities of the sericulture sector are mainly classified into the primary sector or pre-cocoon sector, which involves host plant cultivation, silkworm rearing, seed production, and secondary or post cocoon sector, which involves spinning \& reeling of cocoons, twisting, weaving, finished goods making, and trading.

\section{Present Status of Sericulture Sector in India}

India is renowned for being the only country globally that enjoys a unique position for producing all the commercially practical silk varieties. The silk industry of India plays a distinctive function in employment generation and foreign export for the country. India is the second-largest producer of raw silk worldwide after China, and it is the largest consumer of raw silk in the world. In 2019, India produced about 35,820 Metric Tonnes (MT) of raw silk, contributing about 32.82 percent ofglobal raw silk production.

Mulberry and Vanya silk production in India: Mulberry silk accounts for about 70.46 percent of the country's total silk production, while non-mulberry silk accounts for 29.53 percent of the country's total silk production i.e. tasar, eri and muga individually contribute 8.75 percent, 20.11 percent, and 0.67 percent respectively of total silk production in India. Table 1 shows the total mulberry and vanya silk production in the country. When the production data are compared from 2015, the silk production has been increasing in both the mulberry and vanya sector. In 2019-20, the total mulberry silk production was $25,239 \mathrm{MT}$, and the vanya silk production was 10,581 MT accounting for a grand total of 35,820 MT. There is an increase of 1 percent total raw silk production during 2019-20 over 2018-19. In the case of bivoltine silk production, 0.3 percent growth has been registered during 2019-20 over the previous year while non-mulberry silk i.e. Vanya silk has attained 4.5 percent growth during 2019-20 over 2018-19.

Table 1: Mulberry and Vanya silk production in India

\begin{tabular}{|c|c|c|c|c|c|}
\hline Particulars & 2015-16 & 2016-17 & 2017-18 & 2018-19 & 2019-20 \\
\hline \multicolumn{6}{|l|}{ MULBERRY } \\
\hline Mulberry (Bivoltine) & 4613 & 5266 & 5874 & 6987 & 7009 \\
\hline $\begin{array}{l}\text { Mulberry (Cross } \\
\text { Breed) }\end{array}$ & 15865 & 16007 & 16192 & 18358 & 18230 \\
\hline $\begin{array}{l}\text { Sub Total } \\
\text { (Mulberry) }\end{array}$ & 20478 & 21273 & 22066 & 25345 & 25239 \\
\hline \multicolumn{6}{|l|}{ VANYA } \\
\hline Tasar & 2819 & 3268 & 2988 & 2981 & 3136 \\
\hline Eri & 5060 & 5637 & 6661 & 6910 & 7204 \\
\hline Muga & 166 & 170 & 192 & 233 & 241 \\
\hline Sub Total (Vanya) & 8045 & 9075 & 9840 & 10124 & 10581 \\
\hline GRAND TOTAL & 28523 & 30348 & 31906 & 35648 & 35820 \\
\hline
\end{tabular}

Sources: www.csb.gov.in.

Export of silk goods: In India, the silk market is operated by both exports and a robust local demand. India exports a considerable quantity of silk goods, and the value of these silk goods is more than 15 percent of the total raw silk production (Bukhari and Kaur, 2019). The major items exported from India include dress materials, ready-made garments, sarees, and materials for interior decoration such as curtains, bedsheets, pillow covers, etc. India exports mainly to 10 countries viz., USA, UK, Hong Kong, German People Republic, Italy, France, Spain, Saudi Arabia, UAE, and Singapore (Bukhari and Kaur, 2019). During 2019-20, India exports about 1745.45 crores of silk goods to other countries. The export earnings from the silk goods have decreased due to its reduction in demand in most estern countries. However, silk goods export to countries like UAE, Nigeria, Sudan, and Thailand has increased, which is a good sign for the country.

Import of silk goods: In India, the demand for silk items is very high. The production of silk according to the demand is less in the country, so India has to import raw silk from the other countries. Raw silk is the major item of imports, accounting for about 69.54 percent of the total imports, followed by fabrics and made-ups 
(Anonymous, 2019). India imports raw silk mainly from China which is cheaper and is of good quality than Indian silk. In 2019-20, the value of import of silk goods was 1535.72 crores.

\section{Covid-19 and its Effect on Sericulture Sector of India}

The Covid-19 has caused a drastic impact globally, affecting all walks of life and resulted in severe disruptions in the world's economic activities. Covid-19 (Corona Virus Disease 2019), caused by SARS-CoV-2 (Severe Acute Respiratory Syndrome Corona Virus-2), was first identified in the Wuhan province of China. With the news of the spread of the virus, along with many countries, India also took precautionary measures by imposing restrictions on the movement of the people and goods from the other countries. Since the attack of the disease created an unusual situation, the Indian Government had swung into action by declaring nationwide lockdown to stop the spread of the virus in the country. Soon with the announcement of the lockdown, all the sectors in the economy were slumped down, and the sericulture sector was not an exception to this. A brief account of the problems faced by all the stakeholders, right from farmers to traders involved in the sericulture sector, are given below:

Effect on silkworm rearers: Silkworm rearing is an important part of sericulture activities that require utmost care and effort to produce quality cocoons. The major problems faced by the silkworm rearers during the lockdown and post lockdown periods were nonavailability of the inputs, crash in the cocoon prices, cocoon transportation problem, and fewer cocoon purchasers or reelers in the market, etc. Several reports depicted that the closure of the silkworm rearing centers had led to the interruption of the sericultural activity. There was non-availability of the chawki worms at Chawki Rearing Centres (CRCs) as they were closed due to lockdown. So, the farmers had to stop silkworm rearing.

Moreover, in Nagaland, the farmers faced problems in collecting leaves as there was the restriction of movement from home, and due to the shortage of leaves, there was crop loss in the state. Due to the sudden lockdown announcement, the rearers could not procure the required and minimum quantity of disinfectants and other essential items required during rearing. The DoS also could not supply the same during the needy period. The State and CSB officials were unable to provide any kind of technical assistance required for successful crop production due to restriction of movement (Neog and Shivaprasad, 2020). Since the import of raw silk from China stopped due to the disease outbreak, the cocoon prices increased locally. During the initial days of disease outbreak in the country, i.e., in January and February, the cocoon producers were delighted with the increased profit from selling cocoons. However, after that due to complete lockdown in the country, the cocoon price fell more than 70 percent, which left many of the farmers in distress.

According to Sericulture Farmers' Welfare Association, Ramanagaram, the price of the cross-breed cocoons had fallen to ₹ 130 - ₹ 150 per $\mathrm{kg}$ and similarly superior highquality bivoltine cocoons to ₹ 170 - ₹ 220 per $\mathrm{kg}$. The largest cocoon market in Asia, Ramanagaram cocoon market, remained shut for a week from March 25 to April 21 due to the country's nationwide lockdown. After it reopened on April 2, the price of the cocoons dropped and fewer cocoon purchasers or reelers in the market. About 850-900 reelers visited the cocoon market daily before the outbreak of covid- 19 .

After the market was reopened, only 450-500 purchasers visited the market, of which only 250-300 reelers bought the cocoons from the farmers. The lockdown due to the outbreak of the virus badly hit the expectation of many farmers. Nikhirappa Gadiyappa from the Haveri district of Karnataka had sold his total of $250 \mathrm{~kg}$ of bivoltine cocoons at $₹ 67,500$ i.e., $₹ 270$ per $\mathrm{kg}$, which is a very less return for him. Gadiyappa hardly made a profit of ₹ 20,000 after expending around ₹ 48,000. Another cocoon farmer Chandrashekhar Siddalingaia from Doddaballapur had sold his $166 \mathrm{~kg}$ of cocoon for just ₹ 320 per kg. Since, there was non-availability of buyers in the market, so they were forced to sell their produce at a very lower rate.

Besides these, the farmers also faced transportation problems since many of them used to come from distant places for selling the cocoons, and due to the 
Table 2: Monthly Average Prices of cocoon in 2020

\begin{tabular}{lllllllllllll}
\hline \multicolumn{1}{c}{ Monthly Average Prices of Cocoon } \\
\hline S1. No. & Items & Unit & Jan & Feb & Mar & Apr & May & June & July & Aug & Sept & Oct(P) \\
\hline 1 & $\begin{array}{l}\text { Bivoltine Reeling Cocoon } \\
\text { (Ramanagaram) }\end{array}$ & ₹/kg & 481 & 534 & 439 & 300 & 267 & 274 & 213 & 284 & 282 & 292 \\
2 & $\begin{array}{l}\text { Cross Breed Reeling } \\
\text { Cocoon (Ramanagaram) }\end{array}$ & ₹/kg & 417 & 452 & 371 & 264 & 217 & 214 & 171 & 237 & 231 & 246 \\
\hline
\end{tabular}

Sources: www.csb.gov.in ; P: Provisional data.

Table 3: Monthly Average Prices of silk in 2020

\begin{tabular}{lllllllllllll}
\hline \multicolumn{10}{c}{ Monthly Average Price of Raw Silk, 2020 } \\
\hline Sl. No & Items & Unit & Jan & Feb & Mar & Apr & May & June & July & Aug & Sept & Oct(P) \\
\hline 1 & Raw Silk (Charaka) & ₹/kg & 3105 & 3144 & 3208 & 2556 & 2171 & 1985 & 1816 & 2369 & 2175 & 2186 \\
2 & Raw Silk (Filature) & ₹/kg & 3296 & 3432 & 3461 & 2785 & 2667 & 2478 & 2316 & 2396 & 2384 & 2375 \\
3 & Dupion Silk & ₹/kg & 2137 & 2182 & 2164 & NT & 1744 & 1731 & 1770 & 1576 & 1672 & 1618 \\
\hline
\end{tabular}

Sources: www.csb.gov.in ; P: Provisional data; NT: No Transaction.

non-availability of the vehicles, they encountered inconveniences. Moreover, the boycott of cocoon auction by the cocoon purchaser or reelers had led the farmers to protest by dumping their cocoons on the road in Ramanagaram. After that, many of the farmers temporarily gave up sericulture and shift to the other cultivations due to the constraints faced by them amid the pandemic situation. Ramakrishna Boregowda, a cocoon farmer from Ramanagara, Karnataka, after facing severe losses from silkworm rearing, had cleared his mulberry fields to plant coconut to hope earning money by selling coconuts. Farmers of Anantapur district of Andhra Pradesh had also temporarily stopped sericulture due to silence in the market for several months.

Effect on silk reelers: Silk reeling is an important activity in the silk value chain, which is associated with the conversion of agricultural produce, cocoons into an industrial output, yarn. The major problems faced by the reelers were working capital problems, crash in the silk prices, difficulty selling silk, etc. Due to nationwide lockdown, the reelers were uable to buy the cocoons since they had no money left with them to purchase cocoons as huge quantities of silk remained unsold. The crash in the silk prices had also left the reelers in distress. Mohammed Shafi Ahmed, a silk reeler, said they used to sell ₹ 3500 - ₹ 4000 for a kg of silk yarn, but they had to sell it for only due to price fall ₹1,900 ₹ 2,400 per $\mathrm{kg}$. Table 3 shows the monthly average price of raw silk from January to October 2020.

Fig. 1 shows the total silk production in India during the covid-19 period. If the total production is compared to before the pandemic period, the silk production was reduced during the pandemic. The lowest total raw silk production in India was from April to June i.e. Quarter 1 (2020-21), as shown in Fig. 1. However, the production got increase to some extent after June.

Effect of weavers and traders: In India, weaving is conducted in both handlooms and power looms. During a crisis, the weavers and traders struggled for survival as there was less demand for fabric in the markets. The business stopped when the lockdown started, and both the weavers and traders were hard hit by the pandemic as it attacked in the peak sale season. Products remained unsold due to the cancellation of the orders by the foreign clients. The export of silk goods completely stopped. The global pandemic had taken the sheen off the silk industries of India, which had been reported to have faced monetary loss. Sualkuchi, popularly known as the 'Manchester of the East' is one of the biggest weaving villages where the entire residents are engaged in silk fabric production, specially muga, eri, and 


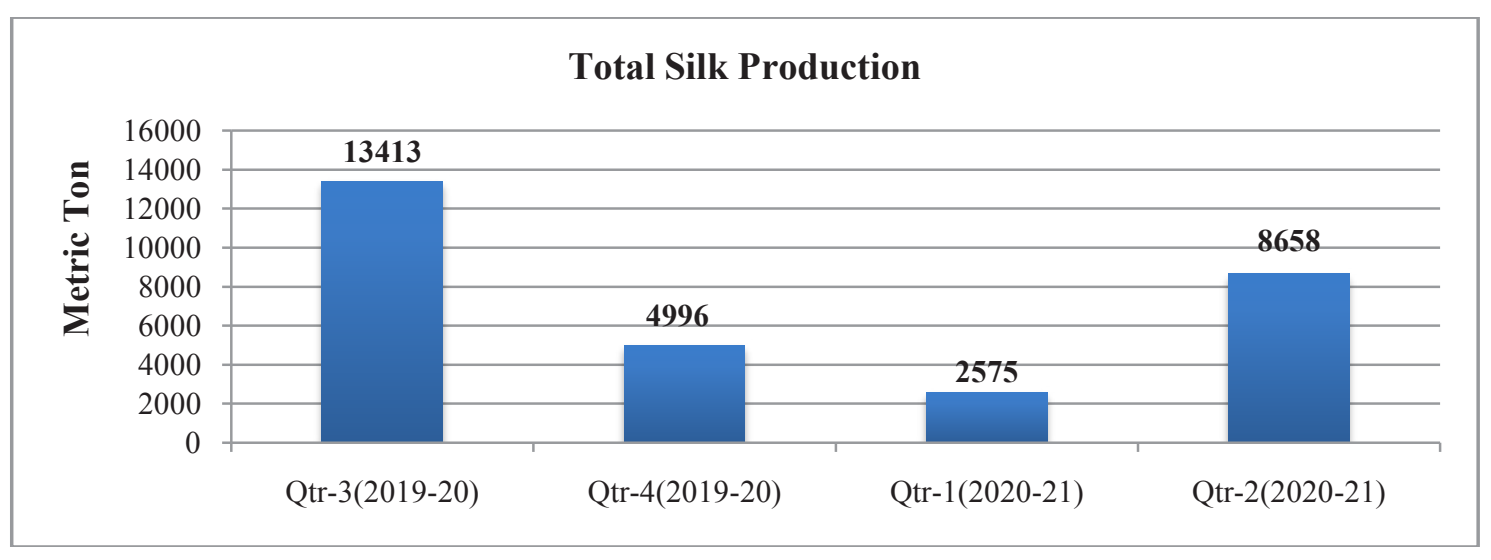

Sources: www.csb.gov.in

Fig. 1: Total silk production from Qtr 3 (2019-20) to Qtr 2 (2020-21)

mulberry. The pandemic struck in the peak sale season i.e., before Bohag Bihu for which the industry incurred a loss of approximately 100 crores. Over 18,000 weavers and allied workers of Sualkuchi and 190 traders faced unprecedented uncertainties due to the pandemic. In the Bhagalpur silk industry, about 10,000 weavers engaged in tasar silk manufacturing also got affected by lockdown. The tasar silk products manufactured in Bhagalpur were sold everywhere in India and also exported to foreign countries. The lockdown stopped the entire business, which left both the weavers and traders in agony.

\section{Government Initiatives}

The relief measures taken by the Government in order to help different stakeholders of sericulture sector from the turmoil of the epidemic are given below:

1. The State government of Karnataka announced a minimum support price of ₹ 50 per $\mathrm{kg}$ of bivoltine hybrid cocoons and ₹ 30 for a $\mathrm{kg}$ of cross-breed cocoons until the market improves.

2. The Department of Sericulture, Karnataka, came forward to help the farmers by connecting them to reelers for selling of the cocoons locally. In Tamil Nadu, with the help of the department staff, around 100 MT of cocoons were directly transacted to reelers. Moreover, the Khadi and Village Industries Commission (KVIC) in collaboration with six Khadi
Institutions (KIs) in Tamil Nadu, came forward by purchasing about $9500 \mathrm{~kg}$ of cocoons directly from the cocoon farmers, worth ₹ 40 lakhs. Accordingly, the tasar cocoons had been sold to the reelers at a proper time in Chhattisgarh.

3. In Tamil Nadu, Tansilk purchased silk from silk reelers through Government Anna Silk Exchange. To purchase raw silk from the reelers, the Karnataka government released ₹ 20 crore to Karnataka Silk Marketing Board (KSMB) and directed to buy 30 $\mathrm{kg}$ of silk from each reeler every week. Moreover, to provide market support to beneficiaries during post lockdown period, the yarn bank of Chhattisgarh purchased raw silk from reelers.

4. A special economic package, "Aatma Nirbhar Bharat Abhiyan" was announced by the Government of India for making India self-relient in which relief measures and credit support were provided to weavers also for reviving their business.

\section{Positive Boon to the Industry}

With the spread of the virus, the face-mask has become an essential item in our day-to-day life. At that point of time, some entrepreneurs came out with unique ideas by making silk face-mask, especially of eri and mulberry. The Khadi and Village Industries Commission also launched a bio-degradable, reusable, and ecofriendly triple-layered silk face-mask, an initiative of 
Atmanirbhar Bharat encouraging the slogan 'vocal for local.

\section{Measures Proposed by Central Silk Board}

To bridge over the impacts caused by nation-wide lockdown due to outbreak of covid-19, Central Silk Board, Bangalore proposed some plan of action required for silk sector to the Ministry of Textiles, Government of India, in order to provide technical support to the sericulture states of India. These include infrastructure support for the farming sector, enhancing bivoltine seed production and cocoon production for securing production growth and price stabilization, respectively, impart training to produce high-grade bivoltine silk and imposing complete ban on import of raw silk from China.

\section{CONCLUSION}

The overall impact of the covid-19 outbreak on the sericulture sector is yet to be determined entirely but it can be said that the impact had been disruptive in most of the leading states of sericulture. The activities involved in the sericulture sector are linked to each other. Since there was a shortage of orders in the market for several months, there was stockpiling of the finished products with the weavers. As the business stopped due to lockdown, the weavers were not in a position to buy silk yarn due to monetary loss faced by them. As a result, the yarn production was hit, leading to no demand of the fresh cocoons, which ultimately affected the silkworm farmers. The Post-cocoon sector is more affected by the covid-19 crisis and subsequent lockdown compared to the pre-cocoon sector. The study, which was conducted by the Central Silk Board covering 1530 stakeholders right from farmers to traders/exporters in Karnataka, Tamil Nadu, Andhra Pradesh, Telangana, and Maharashtra that the more impact was on weaving, trade and export sector compared to reeling and rearing sector.

Though covid-19 has a profound impact on the sector, it is still hoped that in collaboration with the Government, technical persons and development organizations, the sericulture sector will strengthen by overcoming all hindrances.

\section{REFERENCES}

Anonymous. 2019. Annual Report 2018-19, Central Silk Board, Ministry of Textiles, Govt. Of India, Bangalore-560068, India. Pp: 83. www.csb.gov.in

Anonymous. April, 2020. KVIC purchases cocoon from farmers in TN during lockdown; must to steam reared cocoon within 5 days to use for reeling silk yarn. KNNIndia.https://knnindia. co.in/news/newsdetails/msme/kvic-purchases-cocoon-fromfarmers-in-tn-during-lockdown-must-to-steam-rearedcocoon-within-5-days-to-use-for-reeling-silk-yarn

Anonymous. May 2020. Reelers boycott cocoon auction, farmers protest. Deccan Herald. https://www.deccanherald.com/ state/top-karnataka-stories/reelers-boycott-cocoon-auctionfarmers-protest-838503.html

Anonymous. 2020. Note-on-Sericulture-2020-21-Ist-Qtr, Central Silk Board, Ministry of Textiles, Govt. Of India, Bangalore-560068, India, pp. 20. www.csb.gov.in

Anonymous. July 2020. Cocoon price fall: Sericulture farmers to protest. The Hindu. https://www.thehindu.com/news/ national/karnataka/cocoon-price-fall-sericulture-farmers-toprotest/article32061495.ece

Anonymous. August 2020. Support price announced for cocoon in Karnataka. The Hindu.https://www.thehindu.com/news/ national/karnataka/support-price-announced-for-cocoon-inkarnataka/article32358867.ece

Anonymous. September 2020. Effects of Covid-19 Pandemic on Textile Sector. PIB Delhi. https://pib.gov.in/PressReleasePage. aspx?PRID=1656233

Anonymous. September 2020. Production decline, losses hit silk industry value chain. Fibre2FashionNewsDesk.https://www. fibre2fashion.com/news/textile-news/production-declinelosses-hit-silk-industry-value-chain-269996-newsdetails.htm

Bharathi, D. 2016. Sericulture Industry in India-A Source of Employment Generation. Int. J. Adv. Eng. Res. Sci., 3(10): 144147.

Bukhari, R. and Kour, H. 2019. Background, Current Scenario and Future Challenges of the Indian Silk Industry. Int. J. Curr. Microbiol. App. Sci., 8(05): 2448-2463.

Chakrabarti, A. 2020. Handlooms silent, no Bohag Bihu sale: Assam textile hub Sualkuchi fights to survive to Covid. The Print. https://theprint.in/india/handlooms-silent-no-bohagbihu-sale-assam-textile-hub-sualkuchi-fights-to-survivecovid/445994/

Das, A. and Bhagabaty, A. 2018. Study the Problems and Prospects of Rearing of Muga Silkworm (Antheraea assama Westwood) in Boko, Kamrup District, Assam, 3(8): 6-15

Goswami, C. and Bhattacharya, M. 2013. Contribution of Sericulture to Women's income in Assam- A case study in Goalpara District of Assam. Int. J. Scientific and Res. Pub., 3(3): 1-6. 
Karmakar, R. 2020. COVID-19 takes sheen off Assam's silk in Bihu season. The Hindu.https://www.thehindu.com/news/national/ other-states/covid-19-takes-sheen-off-assams-silk-in-bihuseason/article31147289.ece.

Khan, Laiqh A. 2020. Piles of unsold raw silk posing a problem. The Hindu. https://www.thehindu.com/news/national/ karnataka/piles-of-unsold-raw-silk-posing-a-problem/ article31609746.ece

Kumar, C. 2020. Covid impact: Silk cocoon prices fall over $70 \%$ from March. Times ofIndia.https://timesofindia.indiatimes. com/city/bengaluru/covid-impact-silk-cocoon-prices-fallover-70-from-march/articleshow/769938929.c

Kumar, R. 2020. Covid lockdown hit silk weavers. Times of India. https://timesofindia.indiatimes.com/city/patna/covidlockdown-hits-silk-weavers/articleshow/77357986.c

Naseer, T. 2020. Karnataka silk route: cocoon farmers in crisis. Rural India. https://ruralindiaonline.org/articles/karnatakasilk-route-cocoon-farmers-in-crisis
Neog, K. and Sivaprasad, V. 2020. Impact of Covid-19 on the sericulture production in Nagaland. https://www. researchgate.net/publication/344042633-Impact-of-Covid-19on-the-Sericulture-Production-in-Nagaland.

Savithri, G., Sujathamma, P. and Neeraja, P. 2013. Indian Sericulture Industry for sustainable rural economy. Int. J. Econ. Commer. Res., 3(2): 73-78.

Sinha, R.K. 2020. Covid-19: Impact on silk industry-Gloomy situation and the road ahead. Indian Silk, 11(1): 4-8.

Srikanth, S. Guru. 2020. Seven-month market silence hits Anantapur silk farmers hard. NewIndianExpress. https:// www.newindianexpress.com/states/andhra-pradesh/2020/ oct/18/7-month-market-silence-hits-anantapur-silk-farmershard-2211822.html 
